\title{
WT1 Gene Mutation
}

National Cancer Institute

\section{Source}

National Cancer Institute. WT1 Gene Mutation. NCI Thesaurus. Code C146726.

A change in the nucleotide sequence of the WT1 gene. 